\title{
Ewa Bulisz
}

Uniwersytet Marii Curie-Skłodowskiej

\section{Kreatyuność genologiczna we uspółczesnej prasie dla kobiet na przykładzie analizy edytoriali prasowych}

Współczesna prasa dla kobiet jest bardzo zróżnicowana - zarówno pod względem poznawczym, jak i stylistycznym. Badając te dwa aspekty, można wyróżnić następujące jej typy: prasę poradnikową, feministyczną, plotkarską (bulwarową), magazyny luksusowe oraz polskie wersje pism zagranicznych (tzw. kalki). Odmienność ich charakteru wynika poniekąd z profilowania innego wizerunku modelowej adresatki czasopisma oraz z możliwości percepcyjnych samych czytelniczek. Jak zauważa Zofia Sokół „prasa taka jest redagowana pod kątem zainteresowań kobiet w zależności od ich wieku, wykształcenia, zawodu, pochodzenia społecznego, środowiska życia i pracy, roli i miejsca w rodzinie i społeczeństwie" [Sokół 1998: 8]. Wymienione czynniki wpływają nie tylko na profil pisma, ale także na pragmatyczne, stylistyczne i strukturalne ukształtowanie tekstów prasowych. „,W odniesieniu do gatunków wypowiedzi 'kreatywność' wiąże się przede wszystkim z modyfikacjami konwencji gatunkowych" [Wojtak 2009a: 165]. Szczególną kreatywnością genologiczna, czyli bogactwem realizacji różnych wariantów gatunkowego wzorca, wyróżnia się edytorial prasowy¹.

1 Nazwa edytorial pojawiła się stosunkowo niedawno. Przed transformacją ustrojową gatunek ten nazywano wstępniakiem lub artykułem wstępnym. Piętno okresu PRL-u uwidocznione zostało w definicji Zbigniewa Bauera, w której wyjaśnia on, że edytorial to „,komentarz redakcyjny, publikowany w eksponowanym miejscu gazety lub czasopisma. Redakcja (naczelny redaktor lub wydawca) określa tu własną linię polityczną lub wyraża stanowisko jakiejś 
Głównym przedmiotem analizy uczynię zatem edytoriale publikowane na łamach różnych czasopism kobiecych. Uwzględniam zatem: „Zadrę” reprezentującą prasę feministyczną, „Panią" - magazyny luksusowe, "Galę" - czasopisma sytuujące się na pograniczu prasy plotkarskiej i magazynów ekskluzywnych, „,Cosmopolitan” - należący do przedruków, czyli tzw. kalk pism zagranicznych oraz ,,Dobre Rady" - najpopularniejszy miesięcznik w segmencie czasopism poradnikowych.

W niniejszym artykule korzystam z metodologii wypracowanej przez Marię Wojtak, gdyż metodologia ta umożliwia odtworzenie nie tylko wzorca kanonicznego gatunku, ale przede wszystkim jego wariantów alternacyjnych i adaptacyjnych - szczególnie istotnych z punktu widzenia zakładanych celów analizy. Kreatywność redaktorska ujawnia się bowiem najwyraźniej przy przekształceniach ilościowych i jakościowych wzorca kanonicznego oraz w adaptacji cech charakterystycznych dla obcych wzorców gatunkowych [Wojtak 2004a, 2008]. Inwencja twórcza redaktorów decyduje o czterech aspektach wzorca gatunkowego: strukturalnym, pragmatycznym, poznawczym i stylistycznym. Dopiero analiza wszystkich tych komponentów pokazuje, jak odmienne są edytoriale w różnych typach prasy kobiecej.

Zanim jednak przejdę do omówienia wzorców alternacyjnych i adaptacyjnych, warto uściślić, jakie cechy decydują o istnieniu wzorca kanonicznego omawianego gatunku. Wśród podstawowych wyznaczników edytorialu należy wymienić: stałe miejsce druku, nazwę gatunkową lub inny genologiczny indeks, np. Od redakcji ${ }^{2}$, Od redaktora naczelnego, Komentarz, dane osobowe redaktora naczelnego, jego zdjęcie oraz autograf. Składają się one na strukturę tekstu (architektonikę, model kompozycyjny), którą

partii, ugrupowania (o ile pismo pełni funkcję organu prasowego takiej formacji). Często edytorial jest również rodzajem autokomentarza szefa pisma (lub redaktora wydania) do treści prezentowanych $w$ artykułach, zachętą do ich lektury" [Bauer 2010: 270-271].

2 Formuła charakterystyczna dla następujących tytułów: „Twój Styl”, „,Pani”, ,,Wysokie Obcasy”, ,, Cosmopolitan”. 
tworzą nagłówek (nazwa gatunkowa, tytuł, formuła wprowadzająca, ekspozycja), segment główny, czyli korpus oraz formuły finalne. W prasie kobiecej utarły się następujace zuroty otwierające wypowiedź, np. Drogie Czytelniczki, Serdecznie polecam oraz zamykające ją: np. Zachęcam do lektury [Zob.: Wojtak 2005: 113-122]. W czasopismach poradnikowych edytorial ulokowany jest wśród pozostałych gatunków anonsujących, czyli zapowiedzi i spisu treści. Taka praktyka realizowana jest m.in. w: „Dobrych Radach”, ,, Kobiecie i Życiu”, , Poradniku Domowym”, ,, Oliuii” czy „Przyjaciółce”. Natomiast w magazynach luksusowych poświęcona jest mu cała strona, przez co tekst zostaje wyeksponowany i uznany przez redakcję jako ważny. Takie usytuowanie edytorialu występuje m.in. w „Twoim Stylu”, „Pani” i w „Wysokich Obcasach".

Aspekt poznawczy edytorialu uwarunkowany jest przez profil pism. Powiązany jest z pragmatycznymi uwikłaniami komunikatu, czyli obrazem nadawcy i odbiorcy oraz jego celem (potencjałem illokucyjnym). ,,Świat przedstawiony to rzeczywistość bliska określonemu kręgowi ludzi (czytelników pisma i redaktorów), rzeczywistość, którą oni się pasjonują" [Wojtak 2008: 101], inaczej mówiąc: ,,swoi mówią do swoich, entuzjaści komunikują się z entuzjastami" [Wojtak 2006: 116]. Zróżnicowanie form edytorialu sprawia, że nie sposób wymienić wszystkich wyznaczników stylistycznych. Realizacje tekstowe edytorialu pokazują, że jego styl jest zdeterminowany przez tematykę, do której się odnosi (językowy obraz świat, hierarchia wartości, przyjęty punkt widzenia) oraz przez cel komunikatu i jego model kompozycyjny ${ }^{3}$.

Maria Wojtak poddając analizie bogaty i urozmaicony materiał prasowy, wyróżniła następujące odmiany edytoriali publikowanych na łamach prasy specjalistycznej: w formie

3 Maria Wojtak wyróżniła 3 style charakterystyczne dla edytoriali publikowanych na łamach prasy specjalistycznej: styl ,zajawkowy” (zapowiadający inne teksty), styl reklamowy (z typowymi dla reklamy sposobami komunikowania), styl recenzyjny (łączący powiadomienie o zawartości czasopisma z jego rekomendowaniem) [Wojtak 2008: 102]. 
komentarza autonomicznego, kontaminacji komentarza z zapowiedzią oraz $w$ formie tekstu nawiązującego do konwencji recenzji publicystycznej [Wojtak 2008: 98]. Pierwszy z wymienionych wariantów jest charakterystyczny dla magazynów luksusowych, nazywanych także ekskluzywnymi. Oto stosowny przykład realizacji edytorialu $w$ formie komentarza autonomicznego z miesięcznika ,Pani":

Warszawa, marzec 2014

CO JEST PRZYPADKIEM, A CO PRZEZNACZENIEM? I znowu odpowiedź na trudne pytanie? Na tym też polega trud życia codziennego. A więc tak: wszystko, co przypadkowe, wydaje się nam zazwyczaj mniej warte i jakby z samej definicji podważa sens tego, co ze sobą przynosi. Poza tym przychodzi łatwo i przy okazji. A z kolei przeznaczenie autonomicznie wyróżnia nas z tłumu, czyni z nas ludzi naznaczonych miłością, ale i cierpieniem. Może być darem, ale i karą. W swoim kajeciku, w którym od lat zapisuję różne sensacje, znalazłam także i autorstwa Anatole'a France'a: Przypadek jest być może pseudonimem Boga, ale tylko wtedy, kiedy on sam nie chce się podpisać. Ładne, prawda? A jak się bardziej zastanowić, to też bardzo życiowe. Ja sama nie lubię proroctw, wróżek i ich kabał. Kiedyś, jeszcze podczas studiów, w jednej z wrocławskich kawiarni o małej nazwie Hawana przysiadł się do naszego stolika nieznany mężczyzna. Niepytany, a tym bardziej nieproszony przez nikogo, zaczął przepowiadać nam przyszłość. Zapamiętałam własną i przyjaciółki. Do dziś zgadza się liczba mężów i dzieci. Był łaskawy, bo roztoczył przed nami wizję długiego życia. Czas pokaże. I mimo że był jakiś taki bez wyrazu, to wydaje mi się, że i dziś bez problemu potrafiłabym stworzyć jego portret pamięciowy. Tyle tylko, że nadal żyję w przeświadczeniu, że wszystko ma swój czas i miejsce. I jeśli tak ,nauczymy się" myśleć o sobie, to prędzej czy później będzie TOWARZYSZYŁO NAM POCZUCIE WEWNETRZNEJ RÓWNOWAGI I PEWNOŚĆ, ŻE TO NASZE ŻYCIE TO WŁAŚNIE 
TU I TERAZ. Być może nawet już raz się nam coś zdarzyło... Ale jakie to ma znaczenie, skoro o tym i tak zdecyduje albo przypadek, albo przeznaczenie... pozdrawiam.

M. Domagalik

[,,Pani” 2014: 18]

Architektonika tekstu nawiązuje selektywnie do listu, na co wskazują takie elementy, jak miejsce i data oraz zakończenie: „,pozdrawiam”. Edytorial utrymany został w konwencji zwierzenia osobistego. Redaktor naczelna eksponuje własną osobowość oraz prywatne doświadczenia. Wpływa to na utrymanie relacji przyjacielskich z odbiorcą tekstu [Wojtak 2006], a także decyduje o uwiarygodnieniu treści. Całość została oparta o przywołaną historię, w której redaktorka nawiązuje do prywatnych przeżyć z przeszłości. W wypowiedzi dominuje ton refleksyjny, a główną intencją jest poszukiwanie odpowiedzi na pytania natury egzystencjalnej - czy ludzkim losem kieruje przypadek, czy przeznaczenie? Tok rozmyślań redaktorki jest wyeksponowany dodatkowo przez użycie wielokropków i pytań retorycznych.

Analiza tekstu dostarcza informacji o odbiorcy, z którym redaktorka wyraźnie się utożsamia. Wskazują na to zaimki w 1. os. I. mn., np. , wydaje się nam”, czy też zastosowanie czasowników w 1. os. l. mn., np. „nauczymy się”. Ujawnia to wspólnotę wartości i poglądów nadawcy oraz odbiorcy. Wpleciona w tekst sentencja: „Przypadek jest być może pseudonimem Boga, ale tylko wtedy, kiedy on sam nie chce się podpisać" - zmusza odbiorcę do kontemplacji i aktywnego uczestniczenia w lekturze.

W przywołanym edytorialu nie występują natomiast elementy zapowiadające i rekomendujące artykuły z wewnątrz czasopisma, co podkreśla autonomiczny charakter komentarza redakcyjnego, czyli samodzielnego i niestowarzyszonego z innym tekstami.

W prasie poradnikowej gatunek ten, tak jak już wspomniałam, umiejscowiony jest wśród innych komunikatów anonsujących zawartość pisma, m.in. obok spisu treści i zapowiedzi. Usytuowanie 
edytorialu może decydować o jego pragmatycznym i stylistycznym ukształtowaniu, co dobrze oddaje poniższy przykład z miesięcznika ,Dobre Rady":

W tym numerze znajdziecie mnóstwo rad, które naprawdę ułatwia życie. Dzięki podpowiedziom naszych stylistów odkryjecie własny styl (s. 12). Dowiecie się, jak rano szybko ujarzmić niesforne włosy (s. 22) i podkreślić swój seksapil (s. 32). Bo piękna i spełniona kobieta jest lepszą żoną i mamą (s. 76). Chcemy Was przekonać, że na wszystko jest sposób. Nawet związek, który stoi nad przepaścią, można uratować. Przeczytajcie niezwykle wzruszające historie par, które pokonały małżeński kryzys (s. 40). Nasi bohaterowie udowadniają, że miłość potrafi zwyciężyć wszystko!

Agnieszka Wierzbicka, p.o. Redaktor Naczelnej [,Dobre Rady" 2014: 3]

Powyższy tekst jest przykładem realizacji stylu ,,zajawkowego", zapowiadającego treści publikowane na łamach danego wydania. Potwierdzeniem tego są liczne formuły odsyłające do konkretnej strony, które zostały umieszczone wewnątrz tekstu. Jednak edytorial zawiera elementy stylu reklamowego oraz recenzyjnego, który wyraźnie uwydatnia już pierwsze zdanie o charakterze silnie waloryzującym zawartość czasopisma: „,W tym numerze znajdziecie mnóstwo rad, które naprawdę ułatwią życie” [„,Dobre Rady” 2014: 3]. Redakcja wykorzystuje formę edytorialu do prezentacji najciekawszych materiałów z numeru. Nie stosuje wyszukanych chwytów i korzysta z szablonowych wyrażeń, np. ,,w tym numerze”. Odbiorca tekstu jest zbiorowy, na co wskazują czasowniki w 2 os. l. mn.: ,znajdziecie”, ,odkryjecie”, ,dowiecie się”, ,,przeczytajcie”. Komunikat zyskuje silne nacechowanie perswazyjne poprzez użycie zwrotu: „chcemy Was przekonać”. Całość nie jest wyszukana pod względem stylistycznym, co potwierdza używanie obiegowych, utartych wyrażeń: stać nad przepaścia, miłość potrafi zwyciężyć wszystko. 
Po analizie warstwy semantycznej komunikatu możemy stwierdzić, że modelową adresatką czasopisma jest stereotypowa pani domu, która łączy role matki i żony, i potrzebuje wskazówek oraz rad, które mogą ułatwić jej prowadzenie domu i wykonywanie codziennych obowiązków. Redakcja przedstawia siebie „w roli przyjaciół, powierników, doradców - osób, które wybawią z codziennych kłopotów" [Wojtak 2006: 126]. Wraz ze swoimi czytelniczkami tworzą jedną, solidarną wspólnotę kobiet, które borykają się z tymi samymi problemami.

Swoboda $w$ redagowaniu edytoriali owocuje licznymi stylizacjami, tym samym przyczynia się do zwiększenia atrakcyjności samego pisma. W efekcie redakcyjna praktyka wykształca wiele form, które funkcjonują jako tzw. okazy genologiczne. Pojęcie to do genologii weszło za sprawą Marii Wojtak, która definiuje je w następujący sposób: „okaz gatunku to wypowiedź, która zyskuje cechy konkretnego gatunku. Jest mniej lub bardziej dokładną realizacją wzorca gatunkowego" [Wojtak 2008: 164]. Okazy to także „,przejawy kreacji, prowokacje komunikacyjne, zagadki, wręcz łamigłówki dla odbiorcy" [Wojtak 2004b: 36].

Poniższy edytorial prasowy pochodzi z pierwszego wydania czasopisma „Zadra"4. Krakowski kwartalnik popularno-feministyczny skierowany był do szerokiej grupy odbiorców, którzy słabo orientują się we współczesnym dyskursie feministycznym i nie posiadają w tej kwestii wiedzy specjalistycznej.

Na dobry początek

B. K ${ }^{5}$. Teksty do pierwszego numeru ,Zadry” są już gotowe, a my spotkałyśmy się, żeby w rozmowie redakcyjnej - zamiast zwyczajowego "wstępniaka” - przedstawić Czytelniczkom i Czytelnikom ,Zadrę”.

4 Periodyk ukazywał się w latach 1999-2008. W tym okresie wydanych zostało 35 numerów. Kwartalnik jest kontynuacją „Pełnym Głosem”.

5 Umieszczone inicjały nie zostały rozwinięte $w$ tekście. Jednak łatwo je rozszyfrować, bowiem sugerują one następujące imiona i nazwiska osób z redakcji: Beata Kozak (redaktor naczelna), Edyta Krakowiecka (opracowanie graficzne) i Anna Nacher. 
E. K. Czyli „skąd idziemy i dokąd zmierzamy”.

B. K. Najpierw był feministyczny periodyk „Pełnym Głosem". Krakowska eFKA - czyli my - wydała w ciągu kilku lat pięć numerów tego pisma, a teraz proponujemy Czytelniczkom i Czytelnikom nową, bardziej otwartą formułę.

E. K. Trzeba konkretnie powiedzieć, na czym ta nowa formuła ma polegać. „Zadra” będzie ukazywać się regularnie co kwartał i zwraca się zarówno do kobiet, jak i do mężczyzn. Do osób, które interesuje sytuacja kobiet w Polsce i na świecie i które są zaciekawione feminizmem.

S. W. Które lubią zaglądać pod podszewkę stereotypów utartych opinii i myśleć samodzielnie.

B. K. No tak, to dotyczy i kobiet i mężczyzn.

A. N. Jaka będzie „Zadra”? Zadziorna i przekorna, niepokorna? Owszem. Będzie zadzierać ze wszystkimi? Niekoniecznie: „Zadra” jest pomyślana przede wszystkim jako miejsce do mówienia o sprawach kobiet tu i teraz. Interesujące są dla nas i wzorce kulturowe, które są dla kobiet często jak ciasny gorset, i ich konkretne przejawy we wszystkim, co słyszymy i widzimy. Chociaż... odrobina subwersji... jak myślicie?

E. K. Jasne, wypowiadamy na głos tę zadrę, dajmy jej przestrzeń, przyjrzyjmy się jej. Niech nie będzie gładko i na wysoki połysk, niech będzie chociaż trochę chropowato i inaczej niż zuykle.

S. W. Jesteśmy w takiej sytuacji, że możemy poczytać sobie poważną, ogólnoludzką prasę, a dla odmiany przekartkować lub wziąć do pociągu kolorowe pisma kobiece, w których służy się poradą niemal na każdy temat. Dzieci, maseczki, przystawki, moda, podróże, wystrój wnętr. W prasie ogólnoludzkiej jest nas mało, w kobiecej jesteśmy jedną wielką kobietą. ,Zadra” patrzy na swoje Czytelniczki jak na ludzi płci kobiecej i ma tu szansę ulokowania się w samym środku potrzeb kobiet, które wiele razy opowiadały nam o swoim dyskomforcie podczas lektury prasy ogólnoludzkiej i kobiecej.

A. N. Nazwę dla pisma wymyśliła przy kominku w podkrakowskiej wsi poetka Katarzyna Miller. Dzięki, Kasiu. 
B. K. Na koniec, dziewczyny: nie życzymy Czytelniczkom i Czytelnikom ,,miłej lektury”, w końcu nie po to nazywamy się ,Zadra”, prawda?

E. K. Dobrze. Życzymy więc lektury z pazurem i zadrą, ciekawej i inspirującej!

[,Zadra” 1999: 3]

Już na pierwszy rzut oka widać, że edytorial ten nie realizuje wzorca kanonicznego. Bowiem tekst pod względem strukturalnym nawiązuje do konwencji rozmowy redakcyjnej (kolegium redakcyjne). Zamiast typowej wypowiedzi monologowej redaktora naczelnego, występuje konstrukcja dialogowa. Analiza wskazuje, że jest to zapis swobodnej, spontanicznej rozmowy redaktorek ,,Zadry", dobitnie uwydatniają to liczne ucięcia - sygnalizowane wielokropkiem, pytania, kolokwialne $w$ istocie struktury syntaktyczne oraz leksemy potoczne, np. „dzięki”. Zauważalny jest ponadto brak wyrazistych sygnałów gatunkowych. Redukcji ulegają takie elementy, jak: zdjęcie redaktora naczelnego, czy podpis (autograf). Dookreślenie gatunku pojawia się w tekście poprzez użycie nazwy gatunkowej - 'wstępniak'.

Intencją redakcji jest zaprezentowanie czasopisma, wyraźne określenie treści, jakie będą publikowane na łamach „Zadry” (m.in. sytuacja kobiet w Polsce i na świecie, wzorce kulturowe, feminizm, miejsce do mówienia o sprawach kobiet tu i teraz) oraz pośrednio autoprezentacja samej redakcji. Godne odnotowania jest wartościowanie własnego pisma, które na tle prasy kobiecej kreuje się na periodyk wyjątkowy, otwarty, tolerancyjny, niepowielający utartych stereotypów i wyraźnie odcinający się od prasy poradnikowej. Kpiąc i ironizując, redaktorki ujmują istotę tej prasy w następujących słowach: ,,służy się poradą niemal na każdy temat. Dzieci, maseczki, przystawki, moda, podróże, wystrój wnętrz" [,Zadra" 1999: 3].

W analizowanym edytorialu wyraźnie zostali wskazani adresaci wypowiedzi oraz pisma (,Czytelniczki i Czytelnicy”), czyli zarówno kobiety, jak i mężczyźni, co nie jest charakterystyczne dla prasy kobiecej. Więcej informacji o odbiorcach dostarcza analiza 
stylistyczna edytoriali. Można założyć, że powinni nimi być ludzie wykształceni, potrafiący dla przykładu frazę: ,,skąd idziemy i dokąd zmierzamy" odczytać jako aluzję do tytułu obrazu Paula Gauguina „Skąd przychodzimy? Kim jesteśmy? Dokąd zmierzamy?”, czy też zrozumieć znaczenie wyrazów z rejestru naukowego, np. „,subwersja”. Ponadto w tekście użyto kilku frazeologizmów aktywizujących odbiorców: np. zaglądać pod podszewkę6 (być ciekawskim, wścibskim, odkrywać prawdziwą naturę), ciasny gorset ${ }^{7}$ (coś krępującego, ograniczającego swobodę), na wysoki połysk ${ }^{8}$ (idealne, bez skazy), zrobić coś z pazurem ${ }^{9}$ (odważnie, walecznie). Występuje także gra słów: ,zadziorna, przekorna, niepokorna”. Tekst jest wpisany w klamrę kompozycyjną, którą tworzy tytuł: „Na dobry początek” oraz ostatnie słowa redaktorek: ,na koniec, dziewczyny: nie życzmy Czytelniczkom i Czytelnikom miłej lektury". Zaprzeczenie utartej formule - Życzymy przyjemnej lektury - jest dowodem na to, że poddany analizie edytorial nie respektuje zasad kanonicznego wzorca gatunkowego.

Prasa plotkarska jest zdominowana przez treści mówiące o życiu gwiazd i celebrytów. Ta tendencja ujawnia się także $w$ redagowaniu edytorali, co udowadnia poniższy tekst zapożyczony z miesięcznika „Gala”.

„Miłość mojego życia, ślepa i totalna” - tak o Rzymie mówi Hanna Lis. To miejsce kojarzy jej sięz najszczęśliwszymi chwilami. To tu spędziła 10 lat dzieciństwa i to tu w tajemnicy

6 W Słowniku frazeologicznym języka polskiego pod redakcją Stanisława Skorupki leksem 'podszewka' konotuje następujące znaczenia: „zakulisowe szczegóły jakiejś sprawy, ukrywane tło" [Skorupka 1985: 705]. W Słowniku frazeologicznym PWN pojawia się wyrażenie 'znać kogoś od podszewki', które znaczy tyle co ,znać kogoś bardzo dobrze, w najdrobniejszych szczegółach” [Kłosińska 2007: 326].

7 'Ciasny gorset' - ,(damski) pas ściągający dolną część klatki piersiowej, brzuch: nosić, sznurować gorset, ściskać się gorsetem [Skorupka 1985: 254].

8 'Wysoki połysk' - „bardzo starannie, z dbałością o szczegóły” [Kłosińska 2007: 32].

9 'Zrobić coś z pazurem' - ,robić coś z talentem, energią, zapałem, w czymś uzewnętrznić swój talent, zapał" [Kłosińska 2007: 305]. 
wzięła ślub z Tomaszem Lisem. Zawsze kiedy jest w Rzymie, rozczula się, ,,mięknie” i staje bardziej skłonna do zwierzeń. Postanowiliśmy wykorzystać tę jej słabość:). Towarzyszyliśmy Hannie Lis w jej podróży do stolicy Włoch, w którą zabrała również swoje córki: Annę i Julię. Tam zobaczyliśmy zupełnie inną Hannę. Beztroską, co chwila przypominającą sobie kolejne anegdoty i... pierwsze zakochania. Udało nam się także namówić ją do pokazania zdjęć i pamiątek z tamtego okresu. Bardzo ciekawe doświadczenie, bo takiej jej nie znaliśmy. Zaskoczyła i zachwyciła nas także w zjawiskowej sesji zdjęciowej. Patrząc na nią na zdjęciach, człowiek od razu personifikuje pojęcia la dolce vita. Bezdyskusyjnie słodkie życie ma twarz Hanny Lis :). A skoro już o znanych, których pokazujemy od nieznanej strony, to polecam Państwu jeszcze gorąco wywiad z Magdaleną Stużyńską. Aktorka, którą widzowie pokochali za rolę Marcysi w ,Złotopolskich”, teraz wzbudza $w$ widzach podobne emocje, grając $w$ polsatowskich „Przyjaciółkach”. W zupełnie nowej roli zadebiutuje niebawem również Justyna Steczkowska. Nam po raz pierwszy opowiedziała o ciąży, oczekiwaniu na trzecie dziecko i o tym, jakie prezenty przygotowała na powitanie córeczki. A co my przygotowaliśmy dla Państwa? Oczywiście nową „Galę"! Wiosenną i pełną pozytywnej energii.

Agnieszka Jastrzębska, Redaktor naczelna [,Gala” 2013: 4]

W przytoczonym edytorialu mamy wyraźną adaptację cech gatunkowych sylwetki. Całość została zdominowana charakterystyką bohaterki tego wydania - Hanny Lis. To wokół jej osoby została zbudowana treść komentarza. Czytelniczce sugeruje się, że poznaje intymne szczegóły z życia celebrytki (zakochanie, tajemniczy ślub $z$ Tomaszem Lisem). Całość jest utrzymana $w$ tonie zwierzenia i włączenia odbiorczyni tekstu do kręgu przyjaźni łączącego redakcję, czytelniczkę i samą Hannę Lis. Następnie redaktorka zdradza tajemnice z życia aktorki Magdaleny Stużyńskiej oraz piosenkarki Justyny Steczkowskiej. 
Modelowym adresatem edytorialu jest osoba interesująca się showbiznesem, ale jednocześnie wykształcona i znająca języki. Wskazuje na to chociażby brak tłumaczenia obcojęzycznego zwrotu: ,la dolce vita”. Redakcja wyraźnie nie sugeruje, że odbiorcą tekstu jest kobieta, kierując do czytelników zwrot „Państwo”. Pomimo chęci utrzymania przez redakcję wysokiego stylu wypowiedzi, koncept ten zostaje zaburzony poprzez wykorzystanie elementów z rejestru potocznego: m.in. emotikon - ,::)", licznych wielokropków, neologizmów, np.: „,polsatowskie”, innowacji leksykalnych: „zjawiskowa sesja".

Należy dodać, że edytorial ten charakteryzuje się stylem recenzyjnym [Wojtak 2008: 103], gdyż łączy zapowiedź z rekomendowaniem zawartości czasopisma. Ostatnie słowa redaktor naczelnej mają szczególnie waloryzujący i reklamujący charakter: „A co my przygotowaliśmy dla Państwa? Oczywiście nową "Galę"! Wiosenną i pełną pozytywnej energii" ["Gala" 2013: 4]. Brak tytułu oraz formuły finalnej dowodzi, że analizowany edytorial nie tylko adaptuje cechy innego gatunku (sylwetki), ale także realizuje wzorzec alternacyjny, polegający na redukcji wskazanych elementów.

Innym przykładem realizacji nietypowego edytorialu może być komentarz redaktor naczelnej miesięcznika „Cosmopolitan”. Czasopismo to jest adresowane do kobiet młodych i „wyzwolonych", które są lub pragną być w stałym związku.

Przytoczony poniżej komunikat został osadzony w realiach Świąt Bożego Narodzenia, chociaż $w$ tekście występuje jedynie określenie 'Gwiazdka'. Wyraźną intencją nadawcy jest złożenie życzeń czytelniczkom oraz wskazanie argumentów, dla których warto pokochać święta.

Święta w stylu Cosmo!

Dziewczyny, przekazuję wam świąteczne ucałowania od całej cosmoredakcji i kilka powodów, dla których warto pokochać Gwiazdkę.

Jużza kilka dni będziesz mogła całować się pod jemiołą i kochać pod choinką. 
Kreatywność genologiczna we współczesnej prasie dla kobiet...

Szampan, wino, pierniczki, coś na trawienie i znów szampan...

Twój miś będzie miał wreszcie drugi krawat... i bez obawy będziesz mogła mu podarować kolorowe skarpety!

W końcu nadejdzie dzień, w którym nie będziesz się zastanawiać, co zrobić na kolację.

Niedługo pojawią się wyprzedaże $w$ twoich ulubionych sklepach.

Dostaniesz masę prezentów i... Seks w wielkim mieście - zamówiłaś go przecież aż u czterech osób.

Twoja raczej paskudna żyrafa-termometr znajdzie nowy dom.

Nareszcie wyciągniesz z szafy odjechane kreacje, szpilki z brokatem i ukochane błyskotki.

Twój dom będzie pachniał jak wielkie pudło słodyczy: wanilią, cynamonem, czekoladą, pomarańczami...

Poznasz superfaceta $w$ kolejce po karpia.

Jeszcze tylko trzy miesiące i znowu będzie wiosna.

A kiedy minie świąteczna gorączka, będziesz mogła zanurkować pod kołdrą z ukochanym... i wreszcie wypróbować wszystkie pikantne cosmosztuczki.

Hanna Wolska [,Cosmopolitan” 2006: 6]

Redaktor naczelna początkowo zwraca się do całej grupy czytelniczek, po czym zmienia nadawcę na pojedynczą osobę. Dominująca część tekstu została zbudowana na zasadzie wyliczanki życzeń świątecznych. Występują w niej liczne potocyzmy i kolokwializmy, np.: ,twój miś”, ,,odjechane kreacje”, ,,masa prezentów” oraz wiele neologizmów, np. ,cosmoredakcja”, ,,superfacet”, ,cosmosztuczki". Ponadto pojawiają się innowacje leksykalne, takie jak ,zanurkować pod kołdrą" czy też „ucałowania od cosmoredakcji”. Lektura korpusu pokazuje, że redakcja zakłada, iż bardzo dobrze zna swoje czytelniczki i doskonale orientuje się $w$ tym, jak wygląda życie codzienne każdej z nich. Analizowany edytorial przełamuje konwencje wzorca kanonicznego i jest przykładem kolejnej kreatywności redaktorskiej w praktyce dziennikarskiej. 
Przedstawione analizy pokazują, że edytoriale prasowe publikowane na łamach czasopism kobiecych nie stanowią skostniałej formy przekazu. Realizują one różne warianty alternacyjne i adaptacyjne wzorca gatunkowego, czerpiąc cechy strukturalne, stylistyczne i pragmatyczne m.in. z listu, wywiadu, sylwetki, reklamy, czy nawet życzeń. Wzorzec gatunkowy edytorialu jest bardzo elastyczny i daje możliwości oryginalnego wyboru konwencji, które zadziwiają swą niepowtarzalną formą i ujawniają niezwykłą kreatywność redaktorów prasy kobiecej. Podsumowując, możemy stwierdzić, że cechy, które najbardziej decydują o tożsamości edytorialu - to miejsce druku na pierwszych stronach czasopisma oraz autorstwo, czyli zredagowanie tekstu przez redaktora naczelnego.

\section{Bibliografia}

Bauer Z., Gatunki dziennikarskie, [w:] Dziennikarstwo i świat mediów, Bauer Z., Chudziński E. (red.), Universitas, Kraków.

Loewe I. [2007], Gatunki paratekstowe, Wydawnictwo Uniwersytetu Śląskiego, Katowice.

Pachowicz M. [2009], Wstępniak, czyli piórem redaktora naczelnego, [w:] Język żyje. Rzecz o współczesnej polszczyźnie, Ożuk K. (red.), Wydawnictwo Uniwersytetu Rzeszowskiego, Rzeszów.

Słownik frazeologiczny języka polskiego [1985], Skorupka S. (red.), Wiedza Powszechna, Warszawa.

Słownik frazeologiczny PWN [2007], Kłosińska A. (oprac.), Wydawnictwo PWN, Warszawa.

SokółZ. [1998], Prasa kobieca w Polsce w latach 1945-1995, Wydawnictwo Wyższej Szkoły Pedagogicznej, Rzeszów.

Wojtak M. [2004a], Gatunki prasowe, Wydawnictwo Uniwersytetu Marii Curie-Skłodowskiej, Lublin.

Wojtak M. [2004b], Wzorce gatunkowe wypowiedzi a realizacje tekstowe, [w:] Gatunki mowy i ich ewolucja. Tekst a gatunek, Ostaszewska D. (red.), Wydawnictwo Uniwersytetu Śląskiego, Katowice.

Wojtak M. [2005], Osobliwość genologiczna-edytorial, „Stil”, t. 4, Belgrad.

Wojtak M. [2006], Interakcyjny styl komunikowania w prasie kobiecej, [w:] Teksty kultury. Oblicza komunikacji XXI wieku, Mazur J., Rzeszutko-Iwan M. (red.), Wydawnictwo Uniwersytetu Marii Curie-Skłodowskiej, Lublin. 
Kreatywność genologiczna we współczesnej prasie dla kobiet...

Wojtak M. [2008], Analiza gatunków prasowych, Wydawnictwo Uniwersytetu Marii Curie-Skłodowskiej, Lublin.

Wojtak M. [2009a], Kreatywność $w$ wywiadzie a kreatywność wywiadu, [w:] Język polski. Współczesność. Historia, Książek-Bryłowa W., Duda H., Nowak M. (red.), t. VII, Wydawnictwo Uniwersytetu Marii Curie-Skłodowskiej, Lublin.

Wojtak M. [2009b], W kręgu paradoksów gatunku, czyli o konwencji i kreatywności $w$ felietonie, [w:] Język polski $w$ perspektywie diachronicznej i synchronicznej, Maćkowiak K., Piątkowski C., Wydawnictwo Uniwersytetu Zielonogórskiego, Zielona Góra. 